\title{
IVAN GONCHAROV AND THE IMPERIAL HORIZONS OF THE FRIGATE PALLADA**
}

\author{
Rev. of: Bojanowska, E. M. (2018). A World of Empires: The Russian Voyage \\ of the Frigate Pallada. Cambridge, Mass.; L., The Belknap Press; \\ Harvard Univ. Press. $373+$ VIII p.
}

James M. White

Ural Federal University,

Yekaterinburg, Russia

\begin{abstract}
This review examines Edyta M. Bojanowska's new book on Ivan Goncharov's voyage to Japan and his subsequent travelogue, The Frigate Pallada. In 1852, Goncharov set sail for Japan from St Petersburg in the hope of opening up the reclusive Asian nation for Russian trade. Along the way, he visited London, the Cape colony in South Africa, and numerous ports in Southeast Asia. After visiting China, Japan, and Korea, he landed in Ayan, from whence he travelled back to the imperial capital over land. The account he wrote about his experiences became an instant classic, although the lack of good translations means that it is virtually unknown in the English-speaking world. In her work, Bojanowska examines both The Frigate Pallada as a text and the history of Russia's expedition to Japan. Strongly criticising the Soviet philological tradition which saw Goncharov's work as an anti-colonial text, she argues that the famous Russian writer sought to justify the expansion of Russian and other European empires in Africa, Asia, and Siberia. Nonetheless, Goncharov's book reflects peculiarly Russian traditions of understanding empire and colonialism: equally, she posits, his work does not (and cannot) present a cohesive system of thought, but a 'kaleidoscopic' series of impressions that sometimes contradict The Frigate Pallada's general themes.
\end{abstract}

Keywords: Ivan Goncharov; The Frigate Pallada; $19^{\text {th }}$-century Russian literature; empire; colonialism.

В рецензии рассматривается новая книга Эдиты М. Божановской о путешествии Ивана Гончарова в Японию и его травелоге «Фрегат Паллада».

* The completion of this review was supported by the Russian Science Fund (RNF), project no. 18-18-00216.

** Citation: White, J. M. (2019). Ivan Goncharov and the Imperial Horizons of The Frigate Pallada. In Quaestio Rossica. Vol. 7, № 1. P. 347-353. DOI 10.15826/qr.2019.1.380.

Цитирование: White J. М. Ivan Goncharov and the Imperial Horizons of The Frigate Pallada // Quaestio Rossica. Vol. 7. 2019. № 1. P. 347-353. DOI 10.15826/ qr.2019.1.380.

(c) White J. M., 2019

Quaestio Rossica • Vol. 7 • 2019 • № 1, p. 347-353 
В 1852 г. Гончаров отплыл в Японию из Санкт-Петербурга в надежде открыть закрытую страну для российской торговли. По пути он посетил Лондон, Капскую колонию в Южной Африке и многочисленные порты ЮгоВосточной Азии. После посещения Китая, Японии и Кореи он высадился в селе Аян, откуда отправился в столицу империи по суше. Свои впечатления Гончаров описал в ставшем впоследствии классическим труде. Однако отсутствие качественных переводов на английский привело к тому, что эта книга была практически не известна в англоговорящем мире. В своей работе Божановска рассматривает «Фрегат Паллада» как текст и как историю российской экспедиции в Японию. Она критикует советскую филологическую традицию, воспринимавшую работу Гончарова как антиколониальный текст. Божановска полагает, что знаменитый русский писатель старался оправдать экспансию России и других европейских стран в Африку, Азию и Сибирь. Тем не менее, книга Гончарова отражает специфические русские традиции понимания империи и колониализма. В то же время автор заявляет, что книга Гончарова не представляет (и не может представлять) связной системы мысли, а является «калейдоскопической» серией впечатлений, которая иногда противоречит главным идеям этого труда.

Ключевые слова: Иван Гончаров; «Фрегат “Паллада”»; русская литература XIX в.; империя; колониализм.

In his numerous famous books, the post-colonial scholar Edward Said has argued for a focus on works of literature when studying empire (in particular, see: [Said]). Western literature, he suggests, has frequently been used to construct the image of non-European spaces, thereby rendering them suitable targets for conquest and colonisation. Travelogues in particular can be examined through this lens: allegedly the 'objective' first-hand perspectives of supposedly disinterested eyewitnesses, these accounts frequently clothed the distinctly imperialist frameworks of their narratives under a thin veneer of scientific pretensions. Understood in this light, such works often have more to say about the imperial metropoles producing them than they do about the worlds of the colonialized subjects they seek to describe: in other words, they reveal the racial, social, gender, cultural, and economic hierarchies and structures that undergirded European imperial projects and filtered the experiences of travellers and authors alike.

However, Said and his adherents have sometimes been criticised for neglecting non-Anglophone and non-Francophone European countries (see: [Todorova]). This is particularly the case for Russia: with a few exceptions (such as John Darwin, for whom Russian expansion into Siberia and Central Asia is a process that needs to be placed parallel to Western European expansion into the Americas if we are to understand the way in which Europe surpassed older centres of global power, like the Middle East, India, and China [Darwin]), western scholars have tended to neglect the Russian Empire in their general accounts of worldwide European imperialism. This 
attitude has its Russian mirror, where some Russian scholars assert that the 'joining' (prisoedinenie) of non-Russian territories to the country was a qualitatively different process to European settler colonialism (although its effects, in Siberia at least, were much the same: the deaths of many thousands of natives from disease and warfare, the rapacious exploitation of both natives and the natural environment, and waves of varying intensity of voluntary and involuntary settlers). However, area specialists have begun to use Russian literature as a window onto how tsarist writers structured and understood the Russian Empire [Layton]. This has produced some controversial conceptualisations, such as Aleksandr Etkind's idea of internal colonization, the notion that Russians largely regarded the ethnic core of their territories as a space for imperial experimentation and colonial methods of control and development [Etkind].

It is into this field that Edyta Bojanowska (currently of Yale University) enters with her new work on Ivan Goncharov's voyage to Japan and the travelogue that he subsequently wrote about it. Setting out from St Petersburg in 1852, Goncharov was charged with providing a literary description of the journey. In the course of the trip, he and the crew of the Pallada visited London, the Cape, Java, Manila, Shanghai, Singapore, and Hong Kong: after going to Japan, they also docked in Korea before finally heading back to Russian waters, where Goncharov disembarked to begin a long trip across Siberia. We see why this author and his book are an ideal topic for Bojanowska. Not only did Goncharov visit Siberia, a Russian settler colony where he could describe his understanding of his own country's imperial project, but he also stopped in British, Spanish, and Dutch colonial possessions: this allowed him to evaluate Russia's place in Europe and the nature of the Russian Empire in relation to its peers. This topic of investigation is made all the more fascinating because of the outbreak of war between Russia, France, and Great Britain during the Pallada's voyage, which not only affected the ship's course but also Goncharov's perceptions of Russia's rivals. And although the book is mainly about the Russian and European experience of empire, some sources do allow Bojanowska to comment on how non-European peoples considered the Russians: while neither the imprisoned Xhosa leader Siyolo nor the Macao boat girl whom Goncharov met left descriptions of their encounters, Japanese diplomats noted their impressions of the overweight 'barbarian' and his colleagues.

This, then, is a book predominantly about the Russian conception of empire. Throughout, the author's aim is to deconstruct the mental frameworks through which Goncharov and other Russians approached categories of difference and how they understood themselves as a European and global power. For one thing, when travelling through these far-flung regions, the burning question of Russian national identity ('are we Europeans or not?') faded away, although not completely. The crew of the Pallada moved effortlessly through the white settler societies they visited and were treated as wholly European, but they nonetheless provoked curiosity and comment: Russians were quite rare in these parts of the world. Unsurprisingly, therefore, 
the Russian Empire that Goncharov reflects and describes is part of the wider European expansion into the non-European world.

Bojanowska's choice of subject is further predicated by a peculiar caesura in the English-language historiography: while The Frigate Pallada has been massively popular in Russia since its first publication, it has only seldom been translated into English. Furthermore, as she notes, the few translations that exist [Goncharov, 1965; Goncharov, 1987] are flawed on a linguistic level and are based on truncated Soviet editions [Гончаров, 1940; Гончаров, 1951], ones that sought to disguise or remove racist and imperialist sections from the text: particularly embarrassing to the communist authorities were those parts of the book that describe Eastern Siberia in colonialist terms, as a space in desperate need of a Russian 'civilizing mission' to develop both it and its native inhabitants.

This is in turn connected to one of Bojanowska's core arguments. She frequently notes that Soviet (and, to an extent, post-Soviet) interpretations of The Frigate Pallada characterised the work as an anti-colonial text, something they did by extolling Goncharov's criticisms of the British Empire while ignoring or downplaying sections openly advertising his rampant expansionism, capitalist ethics, and praise for the 'civilising' work of the other European powers (he also positively evaluates the British colonies, despite the fact that the book was written during the Crimean War). Her book, then, is partially supposed to serve as an antidote to this interpretation, offering a vision of Goncharov as an unrepentant imperialist and placing his book into the tradition of colonial literature that served to justify further European conquest, annexation, and exploitation in Africa, Asia, and Siberia.

This seems quite obvious. Goncharov was not travelling around the world for the sake of his health, but because he was a paid diplomat in the service of the Russian state on a traditionally imperial mission: to crack open East Asian markets for the benefit of European powers. The Pallada and its crew were to exploit the opportunity created by the American Commodore Perry only weeks beforehand when he forced Japan to abandon its centuries-long seclusion (indeed, Putianin, the leader of the Russian expedition, was explicitly instructed to wait until Perry's negotiations had reached their conclusion before approaching the Japanese). Certainly, one might note that the Russian approach to the Japanese lacked the direct threats of violence that Perry had employed, but Goncharov leaves no doubt what he desired in the future: a mixture of condescending paternalism (the Japanese are routinely described as naughty children to be disciplined by a stern but loving Russian schoolmaster), the occasional flash of pity, racism, and a fetish for violence, his narrative waxes its most lyrical when describing the potential of Japan if only it were placed under 'responsible' (Russian) management. It is thus no surprise that Goncharov was a zealous supporter of the annexation of the Ussurri river region from Qing China, which took place in 1858. And while Goncharov at least regarded Japan and China as 'nations' (narody), he held no such illusions with regards to 
the peoples ('tribes') of South Africa, whose blackness, for the most part, he describes with disgust.

Given the numerous citations Bojanowska provides (and not only from the text of the travelogue but also from Goncharov's private letters, where he was far more acerbic about the Yakuts, for example), it seems difficult to dispute that The Frigate Pallada certainly belongs in the pantheon of European imperialist texts. However, one question does arise: was the 'anticolonial' reading of the book really so widely affirmed in Soviet scholarship? Her own final chapter (which provides a history of the publication and reception of The Frigate Pallada) seems to put this doubt: a fair few of the Soviet philologists that she cites did indeed criticise the text for its imperialist attitudes, although perhaps not as systematically as might have been desired.

Furthermore, some of the evidence that she cites for a continuation of this interpretation into the post-Soviet era misses its target. For instance, she argues that the presence of informational annotations and pictures in a 2015 e-book version of The Frigate Pallada "authorize" the text, by which she means "the cumulative effect of this massive encyclopaedic paratext is to present The Frigate Pallada as a source of reliable information about the nineteenth-century world. By fleshing out Goncharov's references, the text boxes and illustrations authorize the supposed factuality of Goncharov's account, conveying an impression that young Russian people can confidently learn from the book" [Bojanowska, p. 289-290]. In other words, Bojanowska feels that explanatory notes and pictures give Goncharov's narrative the status of reliable fact rather than flawed perception. This is a rather peculiar criticism when we consider that most good reprints of books from earlier historical periods contain some kind of explanatory apparatus, since even welleducated readers may miss or misunderstand references which would have seemed quite obvious to the original audience. It might be more pertinent to look at this e-book's marketing: is it actually being sold as a textbook?

On the whole, Bojanowska's discussions of The Frigate Pallada are fair: as she repeatedly states, the book is immensely complex and can often defy a single interpretation. In a rather striking image, she suggests her own book is an "imperial kaleidoscope" [Bojanowska, p. 243-244], the ordering of a chaotic jumble of Goncharov's text into a neat scholarly narrative: however, Goncharov's contradictions frequently threaten that coherence. So, just as Goncharov greedily espied Japanese resources, he condemned the British for their bourgeois rapaciousness and profiteering; just as he described the smiles of black women being almost evil, so too did he favourably compare the bodies of native South Africans to those of Russians. In one moment, he seems capable of stepping into Japanese shoes, sympathising with their reluctance to open their country to outside influence: the next moment, he admonishes them for immaturity and seems to relish the use of force against them. As unacceptable as some of Goncharov's racial epithets for non-Europeans are to the modern reader, Bojanowska locates his attitude to race appropriately, not in the scientific racism of the late nineteenth century but in the tradition of Russian physical anthropology recently analysed by Mariia Mogilner 
[Mogilner]: hence the fact that mixed marriages between Yakuts and Russians did not really elicit comment from Goncharov, as compared to some other European observers for whom such a practice threatened racial degeneracy.

Some of these textual tensions were Goncharov's own: a highly perceptive and intelligent man with his own particular narrative strategy that was at odds with traditional anthropological travel writing, it is only to be expected that some of his thinking occasionally entered into discrepancy with otherwise predominant mental frameworks. Some of them, however, belonged to the European imperial ideologies he and his countrymen imbibed, such as the juxtaposition between the 'civilising mission' as a noble endeavour to raise the prosperity of one's fellow man and the everpresent reality of exploitation, violence, and brutality.

The book is not just a deconstruction of Russian imperial and national attitudes; equally, it endeavours to relay a global history of empire in the middle of the nineteenth century, providing much valuable information on 19th-century globalisation, the establishment of colonial societies in South Africa and Southeast Asia, and the massive multinational Russian Empire. It is also a narrative of a story that has not been well told in the West, that of the initially successful Russian effort to crack open the Japanese market: the tale of Commodore Perry is far better known. These histories are told to the reader in a colourful, confident, and commanding way that renders this text highly readable: equally, the analysis is surefooted and sound. Only the occasional misstep can be detected: for instance, on p. 207-208, she seems to mistake a reference to Russias efforts to eradicate the slave trade in the Caucasus [Kurtynova-D'Herlugnan] as praise for the British abolition of the slave trade in 1833.

However, such minor errors are few and far between, and as such they do not dent Bojanowska's achievement. An engaging and accomplished work of scholarship, her book ably contributes to the growing literature that attempts to see empire through a Russian prism and seeks to include the Russian case in global histories of European imperialism in both the early modern and modern epochs. No less than, she puts Goncharov, today known principally in the West for his novel Oblomov, in a new light, both as a travel writer and as an imperialist. One can only hope that this book might spur a new translation of The Frigate Pallada into English so that a much wider international audience can read this complex, multifaceted, and intriguing text for themselves.

\section{Список литературы}

Гончаров И. Фрегат «Паллада»: Очерки путешествия. М. : Военмориздат, 1940. $296 \mathrm{c}$.

Гончаров И. Фрегат «Паллада»: Очерки путешествия / ред. С. Д. Муравейский. М. : Географгиз, 1951. $709 \mathrm{c}$.

Bojanowska E. M. A World of Empires : The Russian Voyage of the Frigate Pallada. Cambridge ; MA / L. : The Belknap Press of Harvard Univ. Press. 373 + VIII p. 
Darwin J. After Tamerlane : The Rise and Fall of Global Empires. L. : Allen Lane, 2008. $592 \mathrm{p}$.

Etkind A. Internal Colonization : Russia's Imperial Experience. Cambridge : Polity, 2011. $300 \mathrm{p}$.

Goncharov I. The Voyage of the Frigate 'Pallada'/ ed. and transl. by N. W. Wilson. L. : The Folio Society, 1965. 266 p.

Goncharov I. The Frigate Pallada / transl. by K. Goetze. N. Y. : St Martin's Press, 1987. $650 \mathrm{p}$.

Kurtynova-D'Herlugnan L. The Tsar's Abolitionists : The Slave Trade in the Caucasus and Its Suppression. Leiden : Brill, 2010. 208 p.

Layton S. Russian Literature and Empire : Conquest of the Caucasus from Pushkin to Tolstoy. Cambridge : Cambridge Univ. Press, 2008. 372 p.

Mogilner M. Homo Imperii : A History of Physical Anthropology in Russia. Lincoln : Univ. of Nebraska Press, 2013. 504 p.

Said E. Culture and Imperialism. L. : Vintage, 1994. 528 p.

Todorova M. Imagining the Balkans. Oxford : Oxford Univ. Press, 2009. 288 p.

\section{References}

Bojanowska, E. M. (2018). A World of Empires: The Russian Voyage of the Frigate Pallada. Cambridge, MA/L., The Belknap Press of Harvard Univ. Press. 373 + VIII p.

Darwin, J. (2008). After Tamerlane: The Rise and Fall of Global Empires. L., Allen Lane. $592 \mathrm{p}$.

Etkind, A. (2011). Internal Colonization: Russia's Imperial Experience. Cambridge, Polity. 300 p.

Goncharov I. (1965). The Voyage of the Frigate 'Pallada' / ed. and transl. by N. W. Wilson. L., The Folio Society. 266 p.

Goncharov I. (1987). The Frigate Pallada / transl. by K. Goetze. N. Y., St Martin's Press. 650 p.

Goncharov, I. (1940). Fregat 'Pallada': Ocherki puteshestviia [The Frigate 'Pallada': Travel Essays]. Moscow, Voenmorizdat. 296 p.

Goncharov, I. (1951). Fregat 'Pallada': Ocherki puteshestviia [The Frigate 'Pallada': Travel Essays] / ed. by S. D. Muraveiskii. Moscow, Geografgiz. 709 p.

Kurtynova-D'Herlugnan, L. (2010). The Tsar's Abolitionists: The Slave Trade in the Caucasus and Its Suppression. Leiden, Brill. 208 p.

Layton, S. (2008). Russian Literature and Empire: Conquest of the Caucasus from Pushkin to Tolstoy. Cambridge, Cambridge Univ. Press. 372 p.

Mogilner, M. (2013). Homo Imperii: A History of Physical Anthropology in Russia. Lincoln, Univ. of Nebraska Press. 504 p.

Said, E. (1994). Culture and Imperialism. L., Vintage. 528 p.

Todorova, M. (2009). Imagining the Balkans. Oxford, Oxford Univ. Press. 288 p.

The article was submitted on 07.12.2018 